\title{
Piotr Szczepaniak
}

Uniwersytet Ekonomiczny we Wrocławiu

e-mail: piotr.szczepaniak@ue.wroc.pl

\section{KAPITAŁ WŁASNY W SEKTORACH NIEFINANSOWYCH W POLSCE W LATACH 2009-2011}

\begin{abstract}
Streszczenie: Celem artykułu jest analiza sektorowego zróżnicowania struktury kapitałowej, przeprowadzona z wykorzystaniem wybranych wskaźników finansowych, a także próba ustalenia średniego dla sektorów kosztu kapitału własnego z wykorzystaniem modelu CAPM. Do pomiaru rentowności finansowej wykorzystany został wskaźnik rentowności kapitałów własnych, a do oceny poziomu ryzyka finansowego zastosowano odchylenie standardowe indeksu tworzenia wartości, które wytypowało sektory o największym i najmniejszym ryzyku finansowym. Ponieważ badania obejmują lata 2009-2011, ich wyniki pokazują również zależność liczonych wskaźników od faz cyklu koniunkturalnego.
\end{abstract}

Słowa kluczowe: kapitał własny, koszt kapitału, rentowność kapitałów własnych.

DOI: $10.15611 /$ nof.2014.3.06

\section{Wstęp}

Pojęcie kapitału jest najczęściej definiowane jako całokształt zaangażowanych w przedsiębiorstwie zasobów finansowych, które dzielone są na własne i obce, wewnętrzne i zewnętrzne, terminowe i bezterminowe [Jaworski 2010, s. 231]. Na kapitały własne przedsiębiorstw składają się [Szczęsny (red.) 2012, s. 221; Pomykalska, Pomykalski 2007, s. 40]:

- kapitał podstawowy - utworzony z wkładów właścicieli, przyjmujący w zależności od formy prawnej przedsiębiorstwa nazwę: zakładowy, założycielski czy kapitał właścicieli,

- należne wpłaty na kapitał podstawowy (wartość ujemna) - czyli zadeklarowane, ale niewniesione wkłady na kapitał podstawowy,

- udziały własne - kwota informująca o własnych udziałach przewidzianych do zbycia lub umorzenia,

- kapitał zapasowy - tworzą go: zysk, agio z akcji i dopłaty właścicieli,

- kapitał z aktualizacji wyceny - stanowi korektę wyceny aktywów trwałych,

- pozostałe kapitały rezerwowe, 
- wynik finansowy z lat ubiegłych,

- wynik finansowy netto,

- odpisy z zysku netto w ciągu roku obrotowego (wartość ujemna).

Duże znaczenie udziału kapitałów własnych w kapitale całkowitym oraz wewnętrznej struktury tego kapitału wynika z faktu, że obok funkcji finansującej spełnia on również funkcję gwarancyjną. Ze względu na to, że jest bezterminowym źródłem finansowania, stanowi dla otoczenia informację o poziomie stabilności finansowania majątku przedsiębiorstwa. Dlatego też jednym z celów artykułu jest analiza sektorowego zróżnicowania struktury kapitałowej, przeprowadzona z wykorzystaniem wybranych wskaźników finansowych. Ponieważ kapitały stałe stanowią relatywnie drogie źródło finansowania, kolejnym celem opracowania będzie próba ustalenia średniego dla sektorów kosztu kapitału własnego z wykorzystaniem modelu CAPM. Do pomiaru rentowności finansowej wykorzystany zostanie wskaźnik rentowności kapitałów własnych, a do oceny poziomu ryzyka finansowego zastosowane będzie odchylenie standardowe indeksu tworzenia wartości. Ponieważ badania obejmują lata 2009-2011, ich wyniki pokażą zależność liczonych wskaźników od faz cyklu koniunkturalnego.

\section{Analiza wskaźnikowa kapitałów własnych}

Jednym z podstawowych wskaźników struktury kapitału jest wskaźnik będący ilorazem kapitałów własnych i kapitału całkowitego. W przypadku przedsiębiorstw, w których nie występują pozycje kapitałów niezaliczane ani do własnych, ani do obcych (czyli np. rozliczenia międzyokresowe bierne czy przychody przyszłych okresów), wskaźnik ten w sumie ze wskaźnikiem ogólnego zadłużenia daje wynik 1 [Machała 2004, s. 408]. Wysoki poziom tego wskaźnika świadczy o bezpieczeństwie finansowym, ale również ogranicza możliwość wykorzystania pozytywnego efektu dźwigni finansowej. Wartości wskaźników udziału kapitału własnego w kapitale całkowitym w sektorach niefinansowych przedstawia tab. 1.

Zdecydowanie najwyższym wskaźnikiem udziału kapitałów własnych charakteryzował się w badanym okresie sektor lekki (87\%). Wysoki udział kapitałów własnych odnotowały również sektory: energetyczny, farmaceutyczny, informatyczny i metalowy (około 70\%). Wskaźniki bliskie 30\% udziału kapitałów własnych w kapitale całkowitym cechowały sektory: budowlany i handlowy. Poprawa koniunktury w roku 2010 wywołała wzrost samofinansowania aż w szesnastu sektorach na osiemnaście badanych. Prawie 50-procentowy wzrost wskaźnika odnotował sektor spożywczy, natomiast w sektorach drzewnym i telekomunikacyjnym doszło do obniżenia poziomu wskaźników. W roku 2011 poprawie uległy wskaźniki w piętnastu sektorach, a największym spadkiem wskaźnika dotknięty był sektor lekki (spadek o $37 \%$ ).

Kolejnym wskaźnikiem wykorzystywanym w analizie źródeł finansowania jest wskaźnik zastosowania kapitału własnego. Obliczany jest jako iloraz kapitału włas- 
Tabela 1. Wskaźnik udziału kapitału własnego w kapitale całkowitym w sektorach niefinansowych

\begin{tabular}{|l|c|c|c|}
\hline \multicolumn{1}{|c|}{ Sektor } & $\begin{array}{c}\text { Indeksy dynamiki } \\
\text { wskaźników między } \\
\text { rokiem 2009 a 2010 }\end{array}$ & $\begin{array}{c}\text { Indeksy dynamiki } \\
\text { wskaźników między } \\
\text { rokiem 2010 a 2011 }\end{array}$ & $\begin{array}{c}\text { Wartość średnia } \\
\text { wskaźnika udziału } \\
\text { kapitału własnego } \\
\text { wapitale całkowitym }\end{array}$ \\
\hline Budownictwo & 1,08 & 1,04 & 0,31 \\
\hline Chemiczny & 1,28 & $\mathbf{1 , 4 5}$ & 0,53 \\
\hline Deweloperski & 1,06 & 0,97 & 0,42 \\
\hline Drzewny & 0,98 & 1,10 & 0,36 \\
\hline Elektromaszynowy & 1,05 & 1,03 & 0,58 \\
\hline Energetyczny & 1,01 & 1,08 & 0,69 \\
\hline Farmaceutyczny & 1,10 & 1,21 & 0,70 \\
\hline Handel & 1,02 & 0,74 & 0,32 \\
\hline Hotele i restauracje & 1,17 & 1,12 & 0,64 \\
\hline Informatyczny & 1,27 & 1,15 & 0,87 \\
\hline Lekki & 1,15 & 0,63 & 0,49 \\
\hline Mat. budowlanych & 1,25 & 1,22 & 0,40 \\
\hline Media & 1,07 & 1,35 & 0,70 \\
\hline Metalowy & 1,29 & 1,44 & 0,55 \\
\hline Motoryzacyjny & 1,05 & 1,11 & 0,53 \\
\hline Paliwowy & 1,13 & 1,10 & 0,54 \\
\hline Spożywczy & $\mathbf{1 , 4 9}$ & 1,35 & 0,55 \\
\hline Telekomunikacyjny & 0,92 & 1,00 & \\
\hline Znoto: & & \\
\hline
\end{tabular}

Źródło: opracowanie własne na podstawie: [Internet 5].

nego oraz aktywów trwałych, czyli informuje o tym, jaka część aktywów trwałych została sfinansowana kapitałami właścicieli. Wyższe wartości wskaźnika oznaczają większe bezpieczeństwo finansowe przedsiębiorstwa [Machała 2004, s. 409]. Wartości wskaźników zastosowania kapitału własnego w sektorach niefinansowych przedstawia tab. 2.

W sektorze lekkim kapitały własne aż sześciokrotnie przewyższały wartość aktywów trwałych. W sektorach: budowlanym, elektromaszynowym, informatycznym, metalowym i motoryzacyjnym całość aktywów trwałych była finansowana kapitałami własnymi i jeszcze część majątku obrotowego miała stabilne źródło finansowania pod postacią kapitałów własnych. Rok 2010 spowodował poprawę wartości wskaźników w trzynastu, a rok 2011 w dziesięciu sektorach. Największe spadki wskaźnika w obu latach odnotował sektor lekki, jednak ze względu na wyjątkowo wysokie wartości wskaźnika w tym sektorze nie oznacza to obniżenia bezpieczeństwa finansowania aktywów trwałych. 
Tabela 2. Wskaźnik zastosowania kapitału własnego w sektorach niefinansowych

\begin{tabular}{|l|c|c|c|}
\hline \multicolumn{1}{|c|}{ Sektor } & $\begin{array}{c}\text { Indeksy dynamiki } \\
\text { wskaźników między } \\
\text { rokiem 2009 a 2010 }\end{array}$ & $\begin{array}{c}\text { Indeksy dynamiki } \\
\text { wskaźników między } \\
\text { rokiem 2010 a 2011 }\end{array}$ & $\begin{array}{c}\text { Wartość średnia } \\
\text { wskaźnika zastosowania } \\
\text { kapitału własnego }\end{array}$ \\
\hline Budownictwo & 1,01 & 0,81 & 1,02 \\
\hline Chemiczny & 1,06 & 1,23 & 0,88 \\
\hline Deweloperski & 0,97 & 0,96 & 0,68 \\
\hline Drzewny & 1,02 & 1,06 & 0,48 \\
\hline Elektromaszynowy & 0,94 & 0,88 & 1,19 \\
\hline Energetyczny & 0,97 & 1,00 & 0,88 \\
\hline Farmaceutyczny & 1,10 & 0,83 & 0,97 \\
\hline Handel & 1,06 & 0,86 & 0,66 \\
\hline Hotele i restauracje & 1,17 & 0,84 & 0,74 \\
\hline Informatyczny & 1,06 & 1,01 & 1,06 \\
\hline Lekki & 0,59 & 0,54 & 6,04 \\
\hline Mat. budowlanych & $\mathbf{1 , 2 5}$ & 1,04 & 0,91 \\
\hline Media & 1,03 & 0,95 & 0,58 \\
\hline Metalowy & 1,09 & $\mathbf{1 , 4 4}$ & 1,33 \\
\hline Motoryzacyjny & 1,12 & 1,07 & 1,04 \\
\hline Paliwowy & 1,07 & 1,04 & 0,80 \\
\hline Spożywczy & 1,23 & 1,11 & 0,99 \\
\hline Telekomunikacyjny & 0,94 & 1,00 & 0,66 \\
\hline
\end{tabular}

Źródło: opracowanie własne na podstawie: [Internet 5].

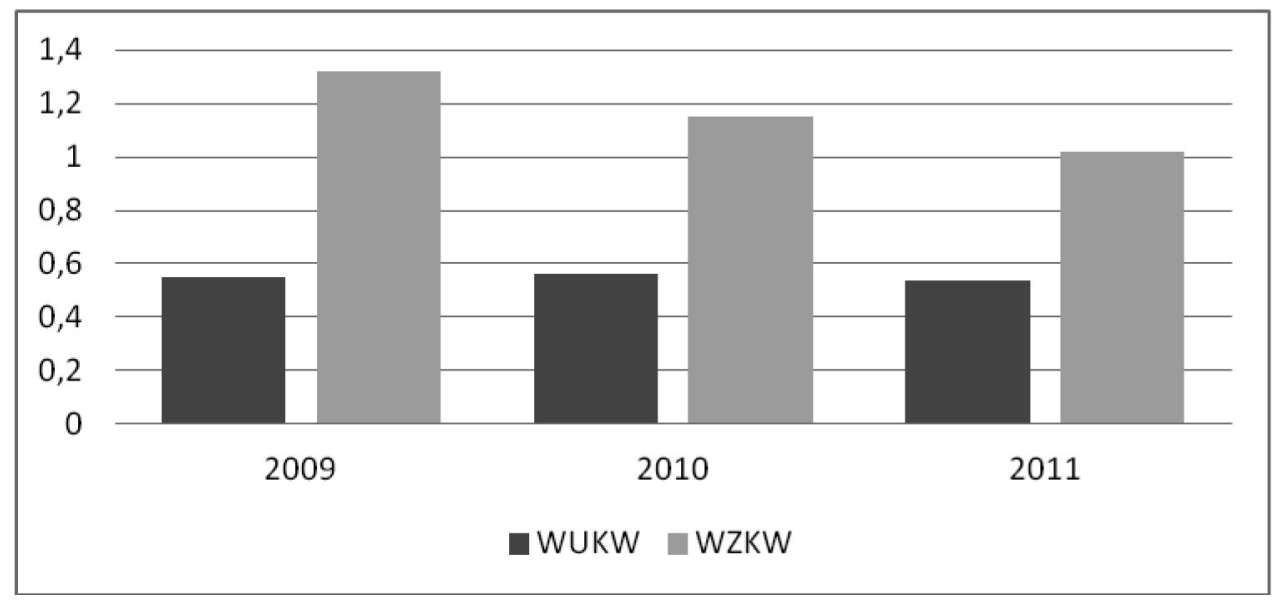

Rys. 1. Wartości średnie wskaźników kapitału własnego dla wszystkich sektorów niefinansowych Źródło: opracowanie własne na podstawie: [Internet 5]. 
Rysunek 1 przedstawia wartości średnie wskaźników kapitału własnego dla wszystkich sektorów niefinansowych w latach 2009-2011.

Wartości średnie wskaźnika udziału kapitałów własnych dla wszystkich sektorów są odporne na cykl koniunkturalny (we wszystkich latach oscylują wokół 55\%), natomiast poprawa koniunktury wywołuje obniżenie poziomu bezpieczeństwa w finansowaniu aktywów trwałych. W roku 2011 wartość wskaźnika dla wszystkich sektorów uległa obniżeniu o 23\% w stosunku do wartości z roku 2009.

\section{Koszt kapitału własnego}

Koszt kapitału jest ceną, jaką płaci kapitałobiorca za możliwość korzystania z kapitału [Michalak]. Koszt kapitału jest najczęściej definiowany jako oczekiwana przez właścicieli i wierzycieli przedsiębiorstwa stopa zwrotu z kapitału zainwestowanego przy danym poziomie ryzyka, które towarzyszy działalności przedsiębiorstwa [Duliniec 2012]. Koszt kapitału własnego może być szacowany metodą bazującą na modelu wyceny aktywów kapitałowych $(C A P M)$. Wzór modelu $C A P M$ jest następujący [Szczepankowski 2004, s. 130]:

$$
R e=R f+\beta *(R m-R f),
$$

gdzie: Re - koszt kapitału własnego,

$R f$ - stopa procentowa wolna od ryzyka (najczęściej stopa zwrotu z inwestycji w obligacje długoterminowe),

$R m$ - oczekiwana rynkowa stopa zwrotu z inwestycji w aktywa kapitałowe (np. w akcje, lub średnia stopa zwrotu osiągana w gospodarce),

$\beta-$-współczynnik stopnia systematycznego ryzyka rynkowego.

Tabela 3 zawiera informację o wartościach średnich z lat 2009-2011 kosztu kapitału własnego w poszczególnych sektorach oraz o indeksach dynamiki kosztu kapitału własnego, wyliczonych w okresach 2009-2010 i 2010-2011.

Najwięcej, ponad $20 \%$, płacono za kapitały własne w sektorach: budowlanym, handlowym, hotelach i restauracjach oraz w lekkim. Kapitały własne były w badanym okresie najtańsze w sektorze energetycznym (koszt niższy od 15\%). Poprawa koniunktury w roku 2010 wywołała spadki ceny kapitałów własnych we wszystkich sektorach, natomiast ponowne pogorszenie koniunktury w roku 2011 spowodowało wzrost kosztu we wszystkich sektorach.

Na rysunku 2, przedstawiającym wartości średnie kosztu kapitału własnego dla wszystkich sektorów niefinansowych, widać silną zależność kosztu kapitału własnego od fazy cyklu koniunkturalnego. W literaturze podaje się dwie daty wybuchu kryzysu finansowego:

- sierpień 2007 r., kiedy banki centralne musiały dokonać interwencji w celu zachowania płynności całego sektora bankowego,

- 15 września 2008 r., kiedy upadł jeden z największych banków inwestycyjnych Lehman Brothers [Sawicka, Rykowska]. 
Tabela 3. Koszt kapitału własnego w sektorach niefinansowych

\begin{tabular}{|l|c|c|c|}
\hline \multicolumn{1}{|c|}{ Sektor } & $\begin{array}{c}\text { Indeks dynamiki Re } \\
\text { między rokiem } \\
\text { 2009 a 2010 }\end{array}$ & $\begin{array}{c}\text { Indeks dynamiki Re } \\
\text { między rokiem } \\
\text { 2010 a 2011 }\end{array}$ & $\begin{array}{c}\text { Średnia arytmetyczna } \\
\text { Re z lat } \\
\text { 2009-2011(\%) }\end{array}$ \\
\hline Budownictwo & 0,983 & 1,009 & 20,33 \\
\hline Chemiczny & 0,983 & 1,009 & 19,52 \\
\hline Deweloperski & 0,981 & 1,010 & 17,7 \\
\hline Drzewny & 0,979 & 1,011 & 16,41 \\
\hline Elektromaszynowy & 0,980 & 1,011 & 17,02 \\
\hline Energetyczny & 0,977 & 1,013 & 14,32 \\
\hline Farmaceutyczny & 0,982 & 1,010 & 18,78 \\
\hline Handel & 0,984 & 1,009 & 21,21 \\
\hline Hotele i restauracje & 0,984 & 1,009 & 20,53 \\
\hline Informatyczny & 0,981 & 1,010 & 17,7 \\
\hline Lekki & 0,985 & 1,008 & 22,56 \\
\hline Mat. budowlanych & 0,981 & 1,010 & 17,63 \\
\hline Media & 0,984 & 1,009 & 20,6 \\
\hline Metalowy & 0,982 & 1,010 & 18,44 \\
\hline Motoryzacyjny & 0,982 & 1,010 & 18,51 \\
\hline Paliwowy & 0,981 & 1,010 & 17,7 \\
\hline Spożywczy & 0,980 & 1,011 & 16,68 \\
\hline Telekomunikacyjny & 0,981 & 1,010 & 18,1 \\
\hline
\end{tabular}

Źródło: opracowanie własne na podstawie: [Internet 5].

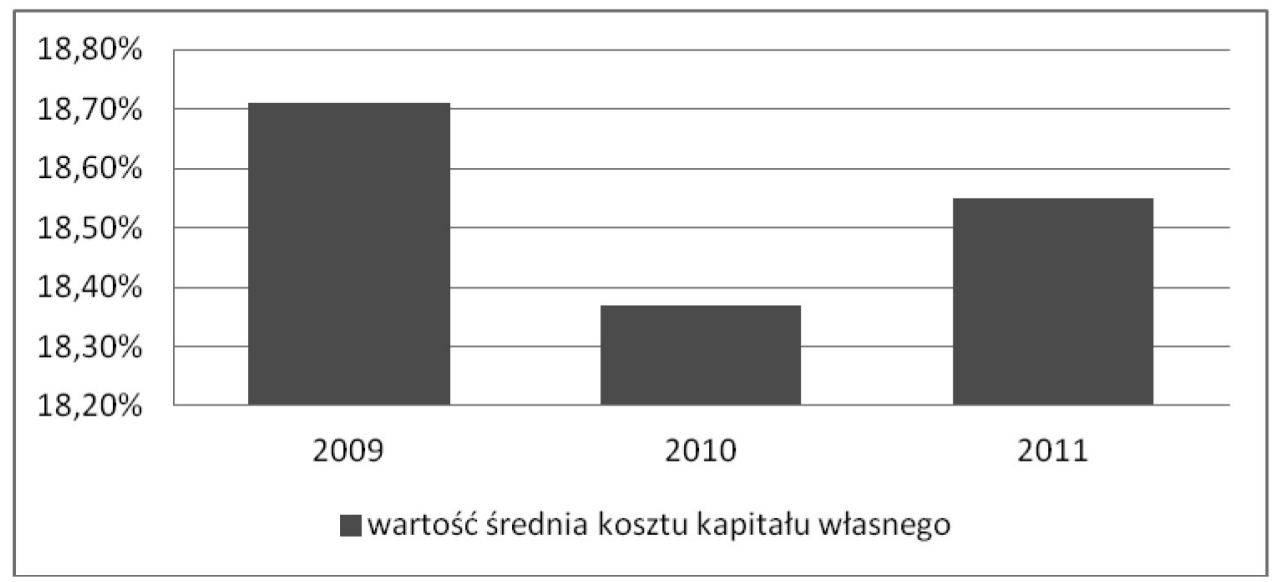

Rys. 2. Wartości średnie kosztu kapitału własnego dla wszystkich sektorów niefinansowych Źródło: opracowanie własne na podstawie: [Internet 1;3;5]. 
Kryzys na rynkach finansowych przeniósł się szybko na gospodarkę realną i sytuację gospodarstw domowych oraz przedsiębiorstw [Nazarczuk]. Kraje strefy euro zaczęły odczuwać skutki kryzysu w II kwartale 2008 r., a Polska w IV kwartale 2008 r., natomiast rok 2009 jest uznawany za okres najgłębszej zapaści polskiej gospodarki i wtedy średni dla wszystkich sektorów koszt kapitału własnego był najwyższy [Internet 4]. Poprawa koniunktury w 2010 r. spowodowała obniżkę średniej dla wszystkich sektorów ceny kapitału własnego o 0,34 punktu procentowego w stosunku do wartości z roku 2009.

\section{Rentowność kapitałów własnych}

Do pomiaru rentowności finansowej wykorzystuje się najczęściej wskaźnik rentowności kapitałów własnych (WRKW), który jest ilorazem zysku netto oraz średniego stanu kapitału własnego. Informuje on, ile czystego zysku netto wypracowuje każda umowna jednostka pieniężna zaangażowana przez właścicieli przedsiębiorstwa. Im wartość WRKW jest wyższa, tym korzystniejsza jest sytuacja finansowa przedsiębiorstwa, a konkretnie jego właścicieli [Pomykalska, Pomykalski 2007, s. 95; Sierpińska, Jachna 2007, s. 104]. Wartości tego wskaźnika dla sektorów niefinansowych przedstawia tab. 4.

Tabela 4. Wskaźnik rentowności kapitałów własnych w sektorach niefinansowych

\begin{tabular}{|l|r|r|r|r|}
\hline \multicolumn{1}{|c|}{ Sektor } & 2009 & 2010 & 2011 & $\begin{array}{c}\text { Średnia } \\
2009-2011\end{array}$ \\
\hline Budownictwo & 19,05 & 14,83 & 11,03 & 14,97 \\
\hline Chemiczny & $-5,44$ & 17,3 & 22,67 & 11,51 \\
\hline Deweloperski & $-0,97$ & 6,33 & $-5,35$ & 0 \\
\hline Drzewny & 0,34 & $\mathbf{1 , 8 9}$ & 8,88 & 3,7 \\
\hline Elektromaszynowy & 5,64 & 5,96 & 11,44 & 7,68 \\
\hline Energetyczny & 9,02 & 7,48 & 10,44 & 8,98 \\
\hline Farmaceutyczny & $\mathbf{- 5 1 , 9 4}$ & 10,63 & 4,06 & $-12,42$ \\
\hline Handel & 9,39 & 5,07 & $-36,54$ & $-7,36$ \\
\hline Hotele i restauracje & 1,51 & 1,96 & 6,21 & 3,23 \\
\hline Informatyczny & 6,55 & 7,91 & 8,45 & 7,64 \\
\hline Lekki & $-16,39$ & 13,05 & $-\mathbf{5 7 , 7 2}$ & $-\mathbf{2 0 , 3 5}$ \\
\hline Mat. budowlanych & 3,11 & 9,06 & 7,65 & 6,61 \\
\hline Media & $\mathbf{1 9 , 9 2}$ & 13,72 & $-0,2$ & 11,15 \\
\hline Metalowy & 19,35 & $\mathbf{2 6 , 7 6}$ & $\mathbf{4 1 , 4 9}$ & $\mathbf{2 9 , 2}$ \\
\hline Motoryzacyjny & 7,93 & 9,73 & 11,3 & 9,65 \\
\hline Paliwowy & 4,64 & 11,39 & 10,01 & 8,68 \\
\hline Spożywczy & 9,8 & 19,51 & 18,64 & 15,98 \\
\hline Telekomunikacyjny & 7,39 & 2,65 & 12,87 & 7,64 \\
\hline
\end{tabular}

Źródło: opracowanie własne na podstawie: [Internet 5]. 
Najwyższą średnią wartość wskaźnika rentowności kapitałów własnych w badanym okresie odnotowano w sektorze metalowym (prawie 30\%). Najgorzej sytuacja przedstawiała się zaś w sektorze lekkim, gdzie średni wskaźnik deficytowości przekraczał -20\%. Lata dekoniunktury (rok 2009 i rok 2011) spowodowały deficytowość finansową w czterech sektorach. W roku 2010 wskaźniki rentowności kapitałów własnych przyjmowały wartości dodatnie we wszystkich sektorach niefinansowych. Najwyższą stopą zwrotu cechował się sektor metalowy (prawie 27\%), a najniższą - drzewny (niecałe $2 \%$ ).

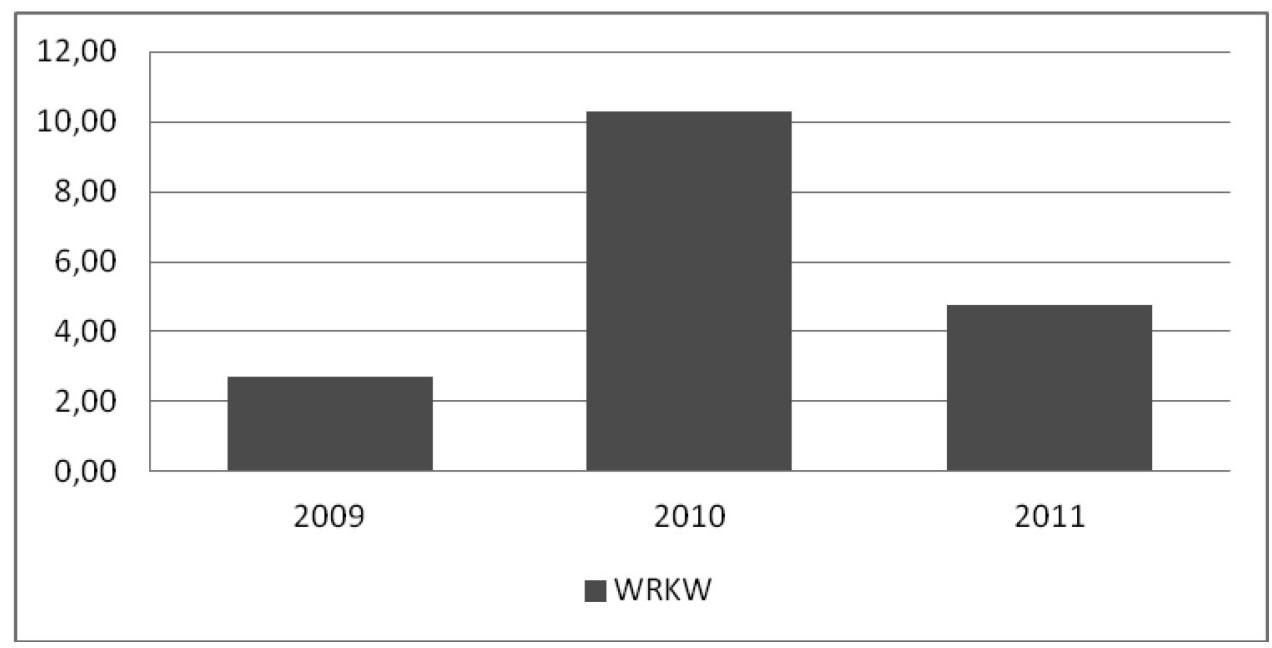

Rys. 3. Wartości średnie wskaźnika rentowności kapitałów własnych dla wszystkich sektorów niefinansowych

Źródło: opracowanie własne na podstawie: [Internet 5].

Rysunek 3 pokazuje silną zależność wskaźnika rentowności kapitałów własnych od faz cyklu koniunkturalnego. W roku 2010 wartość średnia wskaźnika dla wszystkich sektorów wzrosła prawie czterokrotnie w stosunku do wartości z roku 2009, natomiast pogorszenie koniunktury w roku 2011 wywołało spadek wskaźnika o przeszło połowę w stosunku do wartości z roku 2010. Porównując wartości średnie dla wszystkich sektorów kosztu kapitału własnego i wskaźnika rentowności kapitału własnego, można zauważyć, że wyższy koszt kapitału własnego oznacza niższą rentowność kapitałów własnych (rok 2009) natomiast spadek kosztu kapitałów własnych w roku 2010 wywołał wzrost rentowności kapitałów własnych.

\section{Ryzyko finansowe}

Do oceny poziomu ryzyka w finansach stosuje się miary zmienności, czyli inaczej rozproszenia. Mierzą one stopień zróżnicowania jednostek zbiorowości pod wzglę- 
dem badanej cechy. Jedną z najczęściej stosowanych miar zmienności jest odchylenie standardowe. Mierzy ono rozproszenie i przyjmuje wartości nieujemne [Dudycz 1999, s. 85]. Informuje o tym, jakie jest przeciętne odchylenie możliwych wyników od wyniku oczekiwanego, którym może być na przykład wartość średnia [Ostasiewicz, Rusnak, Siedlecka 1997, s. 62]. Miarą poddaną ocenie jest indeks tworzenia wartości, będący ilorazem wskaźnika rentowności kapitałów własnych (WRKW) i kosztu kapitału własnego (Re) [Uziębło 2011, s. 50]. Wynik tego ilorazu wyższy od 1 świadczy o prawidłowym zarządzaniu wartością, ponieważ stopa zwrotu przewyższa koszt kapitału [Internet 6, s. 131].

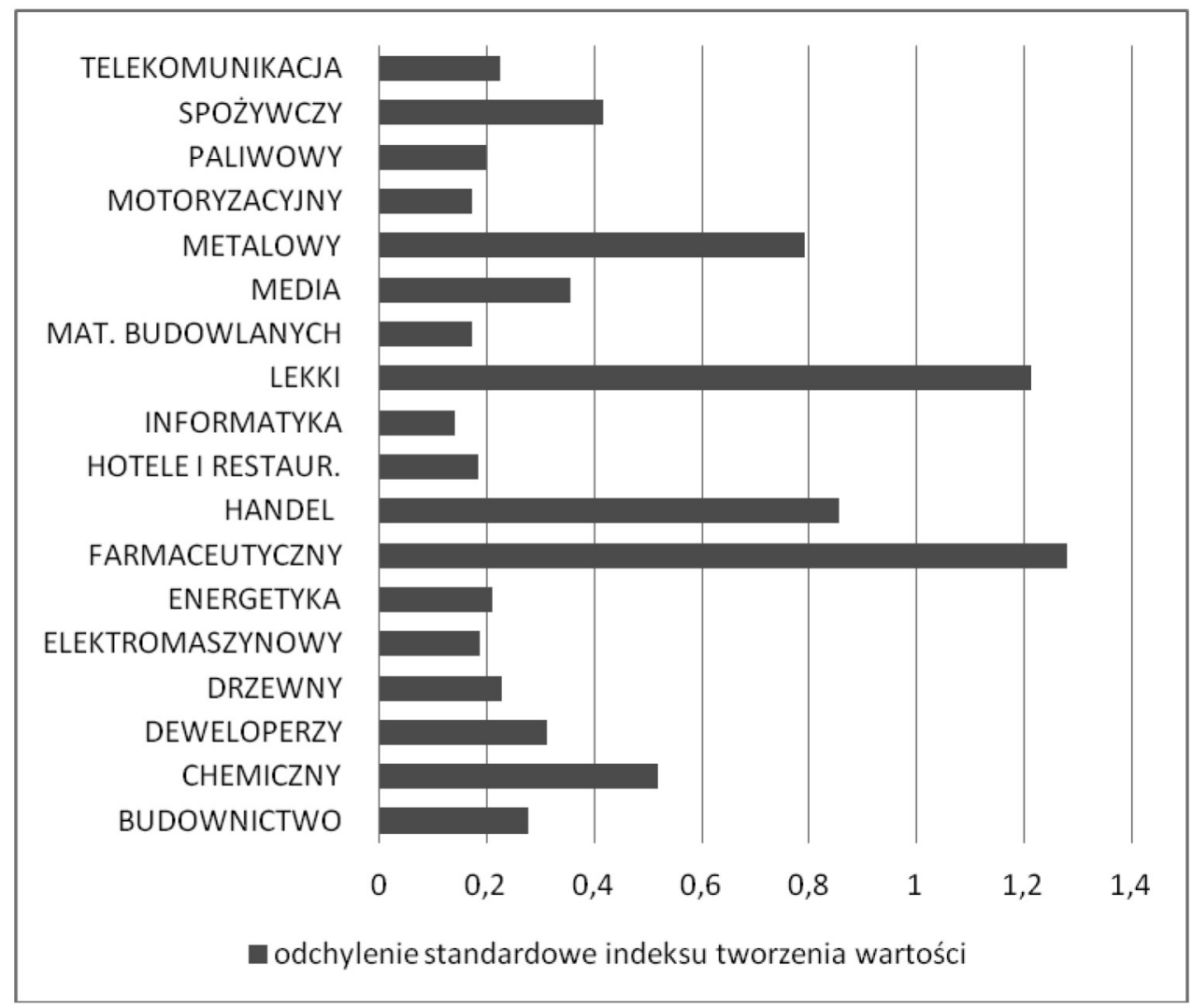

Rys. 4. Odchylenie standardowe indeksu tworzenia wartości poszczególnych sektorów od wartości średniej dla wszystkich sektorów niefinansowych

Źródło: opracowanie własne na podstawie: [Internet $1 ; 2 ; 3 ; 5$ ].

Rysunek 4 zawiera wyliczone dla poszczególnych sektorów odchylenie standardowe indeksu tworzenia wartości w stosunku do wartości średniej tego wskaźnika dla wszystkich sektorów. Sektorami o największym ryzyku finansowym z odchyleniem 
standardowym wskaźnika wyższym od 1,2 okazują się sektory: lekki i farmaceutyczny. Sektorów o zmienności wskaźnika niższej od 0,2 jest sześć: elektromaszynowy, hotele i restauracje, informatyczny, materiałów budowlanych, motoryzacyjny i paliwowy.

\section{Podsumowanie}

Przeprowadzona w artykule analiza wskaźników kapitału własnego wykazała, że najwyższym udziałem kapitałów własnych w kapitale całkowitym charakteryzowały się w badanym okresie sektory: lekki, energetyczny, farmaceutyczny, informatyczny i metalowy. Poprawa koniunktury w roku 2010 wywołała wzrost samofinansowania aż w szesnastu sektorach na osiemnaście badanych, a w roku 2011 poprawie uległy wskaźniki w piętnastu sektorach. W sektorach: lekkim, budowlanym, elektromaszynowym, informatycznym, metalowym i motoryzacyjnym całość aktywów trwałych była finansowana kapitałami własnymi i jeszcze część majątku obrotowego miała stabilne źródło finansowania w tych kapitałach. Rok 2010 spowodował poprawę wartości wskaźników w trzynastu, a rok 2011 w dziesięciu sektorach. Wartości średnie wskaźnika udziału kapitałów własnych dla wszystkich sektorów wykazały się odpornością na zmiany cyklu koniunkturalnego, natomiast poprawa koniunktury wywołała obniżenie poziomu bezpieczeństwa w finansowaniu aktywów trwałych.

Analiza wartości kosztów kapitału własnego pozwoliła zauważyć, że najwięcej płacono za kapitały własne w sektorach: budowlanym, handlowym, hotelach i restauracjach oraz w lekkim. Kapitały własne były w badanym okresie najtańsze w sektorze energetycznym. Poprawa koniunktury w roku 2010 wywołała spadki ceny kapitałów własnych we wszystkich sektorach, a pogorszenie koniunktury w roku 2011 spowodowało wzrosty kosztu we wszystkich sektorach. Wartości średnie kosztu kapitału własnego dla wszystkich sektorów niefinansowych wykazały silną zależność od fazy cyklu koniunkturalnego. Poprawa koniunktury w 2010 r. spowodowała obniżkę średniej dla wszystkich sektorów ceny kapitału własnego w stosunku do wartości z roku 2009, natomiast pogorszenie koniunktury w roku 2011 wywołało ponowny wzrost ceny kapitału własnego.

Najwyższą średnią wartość wskaźnika rentowności kapitałów własnych w badanym okresie odnotowano w sektorze metalowym (prawie 30\%), a najgorzej sytuacja przedstawiała się w sektorze lekkim, gdzie średni wskaźnik deficytowości przekraczał $-20 \%$. Wartość średnia wskaźnika, wyliczona dla wszystkich sektorów, potwierdza silną zależność wskaźnika rentowności kapitałów własnych od faz cyklu koniunkturalnego. W roku 2010 wartość ta wzrosła prawie czterokrotnie względem wartości z roku 2009, pogorszenie koniunktury w roku 2011 wywołało zaś spadek wskaźnika o przeszło połowę w stosunku do wartości z roku 2010. Porównując wartości średnie dla wszystkich sektorów kosztu kapitału własnego i wskaźnika rentowności kapitału własnego, można zauważyć, że wyższemu kosztowi kapitału własnego towarzyszy niższa rentowność kapitałów własnych (rok 2009), natomiast spadek 
kosztu kapitałów własnych w roku 2010 spowodował wzrost wartości wskaźnika rentowności kapitałów własnych.

Sektorami o największym ryzyku finansowym okazały się sektory: lekki i farmaceutyczny, a sektorami najmniej ryzykownymi - sektory: elektromaszynowy, hotele i restauracje, informatyczny, materiałów budowlanych, motoryzacyjny i paliwowy.

Interpretując wyniki przeprowadzonych obliczeń, należy mieć na uwadze, że wyniki analiz i sformułowane wnioski mają charakter bardzo ogólny, ponieważ odnoszą się do sytuacji całych sektorów i nie identyfikują indywidualnej sytuacji poszczególnych spółek.

\section{Literatura}

Dudycz T., 1999, Analiza finansowa, Wydawnictwo Akademii Ekonomicznej we Wrocławiu, Wrocław. Duliniec A., 2012, Koszt kapitału w teorii i praktyce przedsiębiorstw, „Gospodarka Narodowa”, nr 3, www.gospodarkanarodowa.sgh.waw.pl/.../gospodarka_narodowa_2012_03_0.

Jaworski J., 2010, Teoria i praktyka zarzadzania finansami przedsiębiorstw, Ce- $\bar{D}$ eWu, Warszawa.

Machała R., 2004, Praktyczne zarzadzanie finansami firmy, PWN, Warszawa.

Michalak A., Klasyczne a innowacyjne metody szacowania kosztu kapitalu własnego przedsiębiorstwa, www.ue.katowice.pl/.../2_A.Michalak_Klasyczne_a_innowacyjne_metod [dostęp: 25.12.2014].

Nazarczuk J.M., 2013, Wptyw światowego kryzysu finansowego na gospodarkę Polski i jej regionów, [w:] Wybrane aspekty rozwoju regionalnego, R. Kisiel, M. Wojarska (red.), Wydawnictwo Fundacja „Wspieranie i Promocja Przedsiębiorczości na Warmii i Mazurach”, Olsztyn, www.depot.ceon. pl [dostęp: 15.11.2014].

Ostasiewicz S., Rusnak Z., Siedlecka U., 1997, Statystyka. Elementy teorii i zadania, Wydawnictwo Akademii Ekonomicznej we Wrocławiu, Wrocław.

Pomykalska B., Pomykalski P., 2007, Analiza finansowa przedsiębiorstwa, PWN, Warszawa.

Sawicka J., Rykowska J., Wpływ kryzysu gospodarczego na przyszłość Polski w strefie euro, ZN Polityki Europejskie, www.wne.sggw.pl/czasopisma/pdf/PEFIM_nr_53_2010_s341.pdf [dostęp: 15.11.2014].

Sierpińska M., Jachna T., 2007, Metody podejmowania decyzji finansowych. Analiza przykładów i przypadków, PWN, Warszawa.

Szczepankowski P.J., 2004, Zarządzanie finansami przedsiębiorstwa, Wydawnictwo Wyższej Szkoły Przedsiębiorczości i Zarzadzania, Warszawa.

Szczęsny W. (red.), 2012, Finanse firmy. Jak zarządzać kapitatem, Warszawa.

Uziębło A., 2011, Mierniki efektywności ekonomicznej przedsiębiorstwa w opiniach specjalistów z zakresu rachunkowości i finansów, Zeszyty Naukowe WSB we Wrocławiu, nr 27.

\section{Źródla internetowe}

[1] http://pages.stern.nyu.edu/ adamodar/ [dostęp: 15.01.2013].

[2] http://www.bankier.pl/fo/kredyty/components/elw/index.html? [dostęp: 15.01.2013].

[3] http://www.mf.gov.pl/web/wp/dlug-publiczny/publikacje/strategie-zarzadzania-dlugiem.

[4] http://www.mg.gov.pl/NR/rdonlyres/...7236.../wplywkryzysu1902.pdf [dostęp: 15.11.2014].

[5] http://www.rsg.pl [dostęp: 5.01.2013].

[6] http://www.wneiz.pl/nauka_wneiz/sip/sip21-2011/SiP-21-9.pdf [dostęp: 20.01.2013]. 


\section{EQUITY IN NON-FINANCIAL SECTORS IN POLAND OVER THE YEARS 2009-2011}

Summary: The paper aims at analysing the sector differentiation in the equity structure by means of selected financial indicators as well as making an attempt to establish an average equity costs for the sector by means of CAPM model. The return on equity indicator has been used to measure financial profitability while a standard deviation indicator of the value creation index has been used to assess a financial risk which led to indicating sectors with the highest and the lowest financial risk. As the research comprises years 2009-2011 its results also show dependency of calculated indicator on phases of the business sector.

Keywords: equity, equity cost, profitability of equity. 